\title{
VARIASI KOMPOSISI INPUT PROSES ANAEROBIK UNTUK PRODUKSI BIOGAS PADA PENANGANAN LIMBAH CAIR KOPI
}

Variation of Input Composition of Anaerobic Process on Coffee Wastewater Treatment

\author{
Elida Novita $^{1) *}$, Sri Wahyuningsih ${ }^{1)}$, Hendra Andiananta Pradana ${ }^{1)}$ \\ 1) Jurusan Teknik Pertanian, Fakultas Teknologi Pertanian, Universitas Jember \\ Jl. Kalimantan 37, Kampus Tegal Boto Jember 68121 \\ *E-mail: elida_novita.ftp@unej.ac.id
}

\begin{abstract}
Generally, there are two methods of coffee processing beans that are the dry processing and wet processing. The wet coffee processing will produce waste water containing organic materials. The high contain of organic matter in coffee wastewater can be used as biogas through anaerobic process. The biogas production from this processcould have variation of volume and composition depends on their feeding. The purposes of this research were to find the best biogas volume would be produced based on variation of input in batch feeding method (1) and to reduce coffee wastewater concentration by anaerobic process (2). The researched procedures were inoculum production, incubating adaptation and variation of batch feeding into the anaerobic reactor (4 variations). The variation of batch feeding were (1) 1:1; (2) 3:1; (3) 3.7:0.3 for water and (4) 3.6:0.4 for cow dung. The highest biogas volume and pollution load reduction were occurred in batch feeding composition 1:1. The volume of biogas production was $250 \mathrm{~mL}$ at day 6 and the percentage of parameters reduction were COD 57.35\% and BOD 57\%. Based on this research, there were also increasing gas volume from day $2(95 \mathrm{ml})$ up to day $6(250 \mathrm{ml})$ in each batch.
\end{abstract}

Keywords: anaerobic process, biogas, coffee wastewater treatment, input variation

\section{PENDAHULUAN}

Kopi merupakan salah satu komoditas unggulan sektor perkebunan di Kabupaten Jember. Pada tahun 2014, produksi kopi di Jember mencapai 2.491 ton (Dinas Pertanian dan Perkebunan Kabupaten Jember, 2015). Secara umum, terdapat dua metode pengolahan buah kopi menjadi biji kopi yaitu pengolahan kering dan pengolahan basah. Pengolahan basah menghasilkan biji kopi dengan mutu yang lebih baik (Novita, 2012), namun pengolahan basah relatif tidak ramah lingkungan. Pengolahan basah membutuhkan air sebesar 7-9 $\mathrm{m}^{3}$ per ton buah kopi yang diolah (Sariadi, 2012). Menurut Kementerian Pertanian Republik Indonesia (2012), pengolahan basah membutuhkan air sebesar $10-30 \mathrm{~m}^{3}$ per ton buah kopi.

Limbah cair pengolahan kopi memiliki tingkat keasaman yang tinggi sehingga bersifat korosif. Selain itu limbah cair pengolahan kopi memiliki kandungan bahan organik yang tinggi sehingga dapat mengganggu kehidupan organisme air jika dibuang langsung ke badan air. Limbah cair pengolahan kopi memiliki nilai kandungan bahan organik BOD berkisar antara 3.100-14.340 $\mathrm{mg} / \mathrm{L}$ dan COD sebesar 5.000-35.000 mg/L (Bruno dan Oliviera, 2008). Tingginya kandungan bahan organik pada limbah cair pengolahan kopi yang diindikasikan oleh nilai COD dan BOD dapat dimanfaatkan sebagai biogas melalui proses anaerobik. Proses anaerobik akan memecah bahan organik menjadi senyawa yang relatif lebih aman bagi lingkungan dengan penurunan nilai COD, BOD, TSS dan TDS sebesar $90 \%$ (Pramdono dan Susanto, 2007) serta menghasilkan gas metan yang dapat digunakan sebagai sumber energi.

Proses anaerobik secara umum meliputi tahap hidrolisis, asidogenesis dan metanogenesis. Hidrolisis adalah proses pemecahan molekul yang berukuran besar dan kompleks terlarut dan tak terlarut 
menjadi molekul yang berukuran lebih kecil.

Asidogenesis adalah tahap fermentasi dan oksidasi anaerobik yang merubah produk akhir hidrolisis menjadi karbon organikhidrogen dan karbondioksida. Produk akhir tahap asidogenesis adalah asam asetat dan rantai asam lemak yang tidak terpecah pada tahap fermentasi. Tahap berikutnya adalah tahap metanogenesis. Pada tahap ini terjadi pembentukan produk utama proses anaerobik yaitu fermentasi hasil proses asidogenesis berupa asam asetat menjadi metana dan karbondioksida. Asam asetat merupakan sumber utama penghasil biogas yang diproduksi dalam tangki anaerobik. Adapun bakteri yang berperan adalah bakteri asetoklastik (Wahyuni, 2013). Pada tahap ini juga terjadi reaksi pembentukan metana dan air dari karbondioksida dan hidrogen oleh bakteri pembentuk metana (Hydrogenophilic methanogens).

Volume gas metan yang dihasilkan pada proses anaerobik dapat ditentukan oleh karakteristik starter, konsentrasi, dan komposisi umpan yang diberikan. Metode pengisian umpan pada reaktor dapat dilakukan dengan batch feeding. Menurut Utomo et al. (2014), pemberian umpan atau feeding dengan konsentrasi (beban) yang berbeda akan menghasilkan produksi biogas yang berbeda pula. Tujuan dari penelitian yang dilakukan yaitu menjelaskan pengaruh variasi volume dan konsentrasi input limbah cair pengolahan kopi terhadap pola produksi biogas secara batch feeding dan mengetahui penurunan tingkat pencemaran limbah cair pengolahan kopi.

\section{METODE PENELITIAN}

\section{Alat dan Bahan}

Alat yang digunakan dalam penelitian ini yaitu jirigen air, corong kaca merk Herman $50 \mathrm{~mm}$, labu ukur $100 \mathrm{ml}$ dan $500 \mathrm{ml}$ merek Pyrex,beakerglassmerk Pyrex $100 \mathrm{~mL}$ dan $500 \mathrm{~mL}$, cawan alumunium, timbangan digital ohaus, penggaris, oven merk memmert, $\mathrm{pH}$ meter Calibration Check HI 223, $\mathrm{pH}$ meter merek Senz, turbiditimeter TN-N 100, reaktor COD HI 839800 merk Hanna, spketrofotometer HI 83099 merk Hanna, $\mathrm{CO}_{2}$ meter GCH-2018 merk Lutron, pipet, kuvet digester 1 dan digester 2 . Bahan-bahan utama yang digunakan antara lain limbah cair pengolahan kopi, kotoran sapi, aquadest, $\mathrm{NaOH} 1 \mathrm{~N}$ dan $0,1 \mathrm{~N}$, $\mathrm{H}_{2} \mathrm{SO}_{4} 20 \mathrm{~N}$, mangan sulfat $40 \%$, alkali iodida azida,reagent COD HR (High Range) $\mathrm{HI} 93754 \mathrm{C}-5, \mathrm{Na}_{2} \mathrm{~S}_{2} \mathrm{O}_{3} 0,025 \mathrm{~N}$, indikator amilum $0,05 \mathrm{~N}$, reagen $\mathrm{N}$ HI 93728-01 dan $\mathrm{K}_{2} \mathrm{Cr}_{2} \mathrm{O}_{7} 2 \mathrm{~N}$.

\section{Tahapan Penelitian}

Pembuatan desain digester

Desain digester berkaitan dengan konsep inkubasi. Penelitian ini menggunakan starter dari kotoran sapi yang banyak mengandung bakteri metanogen. Metode batch cenderung efektif untuk pembuatan starter sehingga penelitian ini menggunakan dua buah digester. Digester 1 untuk penumbuhan starter dan digester 2 untuk inkubasi adaptasi serta penerapan metode batch feeding. Komponen fungsional pada alat digester 1 yaitu saluran input, saluran outlet, saluran gas, penampung gas, dan saluran uji bakar. Komponen fungsional digester 2 meliputi inlet, saluran gas, penutup bagian atas silinder, penampung gas dan outlet. Desain digester dapat diihat pada Gambar 1.

\section{Pembuatan starter}

Pembuatan starter berasal dari campuran kultur bakteri metanogen kotoran sapi. Berikut ini merupakan penjelasan dari pembuatan starter.

a) Pembuatan starter pada tahap pertama dilakukan dengan perbandingan kotoran sapi dan air sebesar 1:1.

b) Tahapan pembuatan starter meliputi:

1. Menyiapkan 5 liter kotoran sapi dan 5 liter air; 
2. Melakukan pencampuran dan pengadukan kotoran sapi dan air;

3. Memasukkan 10 liter campuran tersebut ke digester 1 dan melakukan inkubasi selama 28 hari.

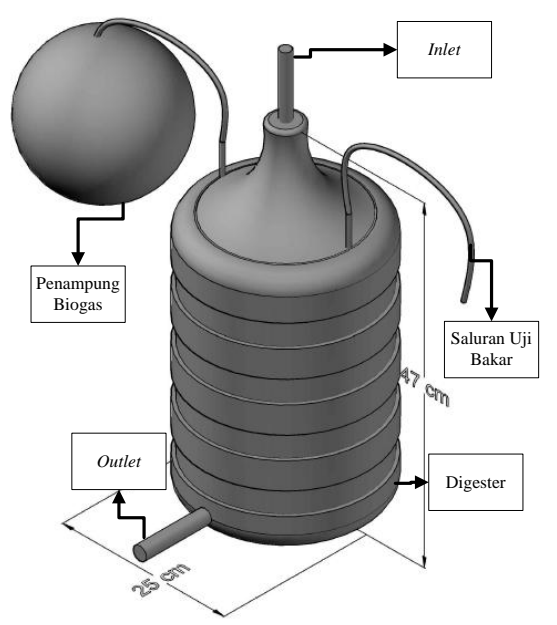

(a)

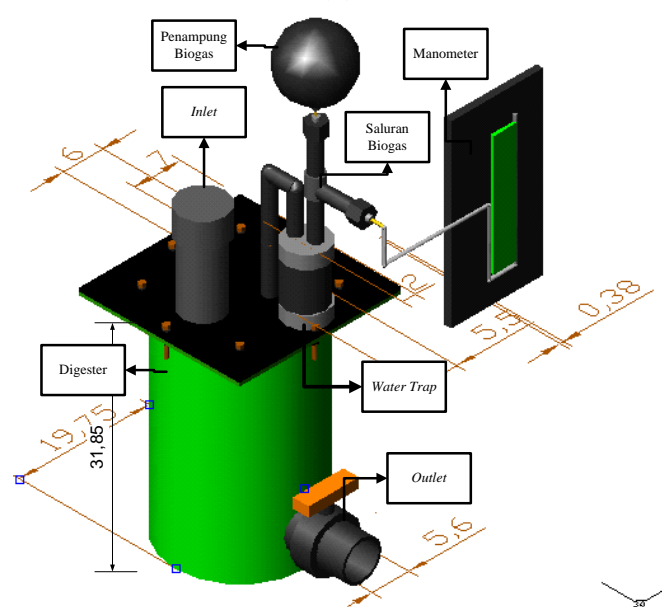

(b)

Gambar 1. Desain digester tiga dimensi (a) digester 1, (b) digester 2

\section{Penetralan $\mathrm{pH}$}

Penetralan kondisi keasaman atau $\mathrm{pH}$ dilakukan agar bakteri metanogen dapat hidup pada lingkungan yang sesuai. Penetralan $\mathrm{pH}$ dilakukan dengan cara melakukan penambahan $\mathrm{NaOH} 0,1 \mathrm{~N}$ ke dalam limbah cair kopi. Jumlah penambahan $\mathrm{NaOH} \quad 0,1 \quad \mathrm{~N}$ dihentikan setelah $\mathrm{pH}$ limbah cair pengolahan kopi memiliki nilai $\mathrm{pH}$ netral sebesar 7,1 (Tabel 1).
Tabel 1. Penetralan $\mathrm{pH}$ starter dan limbah cair pengolahan kopi

\begin{tabular}{lcccc}
\hline Objek & $\begin{array}{c}\text { Volume } \\
(\mathrm{mL})\end{array}$ & $\begin{array}{c}\mathrm{pH} \\
\text { Awal }\end{array}$ & $\begin{array}{c}\text { Volume } \\
\mathrm{NaOH} \\
0,1 \mathrm{~N} \\
(\mathrm{~mL})\end{array}$ & $\begin{array}{c}\text { Penetralan } \\
\mathrm{pH}\end{array}$ \\
\hline $\begin{array}{l}\text { Starter } \\
\text { kotoran }\end{array}$ & 100 & 5,9 & 8 & 7,1 \\
$\begin{array}{l}\text { sapi }) \\
\text { Limbah } \\
\text { cair kopi }\end{array}$ & 100 & 5,2 & 15 & 7,1 \\
\hline
\end{tabular}

\section{Inkubasi adaptasi}

Inkubasi adaptasi dilakukan dengan pemindahan starter dari digester $1 \mathrm{ke}$ digester 2.Selanjutnya ditambahkan limbah cair pengolahan kopi.Limbah cair pengolahan kopi yang sudah diukur karakteristik awal limbahnya, diformulasikan dengan starterdengan perbandingan 1:1. Volume biomassa sebesar 4 liter (2 liter starter dari kotoran sapi : 2 liter limbah cair pengolahan kopi). Inkubasi dilakukan selama 9 hari.Hasil fermentasi pada tahap ini adalah slurry yang siap diberikan feeding.

\section{Pengukuran parameter kualitas limbah cair pengolahan kopi}

Pengukuran parameter awal limbah cair kopi meliputi suhu, pH, COD, BOD, $\mathrm{C}$ dan N. Pengukuran parameter harian selama 35 hari yaitu suhu dan $\mathrm{pH}$ sedangkan parameter yang diukur awalakhir di setiap batch feeding yaitu COD, BOD, C dan N. Berikut ini merupakan metode pengukuran parameter tersebut.
a) Pengukuran $\mathrm{pH}$ dilakukan menggunakan $\mathrm{pH}$ meter setiap hari selama 35 hari inkubasi limbah cair pengolahan kopi.
b) Pengukuran suhu dilakukan menggunakan thermometer setiap hari selama 35 hari inkubasi limbah cair pengolahan kopi.
c) Parameter COD diukur awal-akhir di setiap batch feeding menggunakan metode spektrofotometri. Berikut ini langkah- langkah pengukuran COD:


1) untuk pembuatan blanko yaitu ditambahkan aquades sebanyak 2 $\mathrm{mL}$ ke dalam tabung yang berisi reagent COD HR (High Range) ;

2) selanjutnya untuk pembuatan sampel, ditambahkan limbah cair pengolahan kopi yang telah dinetralkan $\mathrm{pH}$-nya sebanyak $2 \mathrm{~mL}$ ke dalam tabung yang berisi reagent COD;

3) kedua tabung yang telah ditambahkan masing-masing aquades dan limbah ditutup rapat dan dikocok;

4) setelah dikocok, dipanaskan ke dalam COD reaktor pada suhu $150^{\circ} \mathrm{C}$ selama 2 jam

5) setalah dipanaskan menggunakan COD reaktor, kedua tabung didinginkan pada suhu ruangan;

6) kemudian dilakukan pembacaan nilai menggunakan spektrofotometer;

7) pertama dilakukan pembacaan untuk blanko kemudian dilanjutkan dengan sampel.

d) Parameter BOD diukur awal-akhir di setiap batch feeding menggunakan metode winkler. Berikut ini langkah pengukuran BOD:

1) memasukkan sampel limbah cair kopidengan derajat pengenceran 0,001 dan penyiapan blanko pada botol winkler tanpa udara hingga penuh;

2) menambahkan $2 \mathrm{~mL}$ larutan $\mathrm{MnSO}_{4}$ $40 \%$, dan mendiamkan larutan selama beberapa menit untuk menghomogenkan;

3) menambahkan $2 \mathrm{~mL}$ alkali iodida azida, kemudian didiamkan hingga muncul endapan berwarna coklat dan memindahkan larutan ke gelas kimia kemudian dikocok;

4) menambahkan $2 \mathrm{~mL} \mathrm{H} \mathrm{H}_{2} \mathrm{SO}_{4}$ pekat hingga endapan larut, lalu mengambil $\quad 100 \mathrm{~mL}$ dan memindahkan larutan ke dalam Erlenmeyer;
5) larutan yang berada di dalam erlenmeyer siap untuk dititrasi dengan larutan $\mathrm{Na}_{2} \mathrm{~S}_{2} \mathrm{O}_{3} 0,025 \mathrm{~N}$;

6) menambahkan indikator amilum dan melanjutkan kembali dengan titrasi hingga warna biru hilang, kemudian catat volume titrasi.

Perhitungan :

$$
\begin{aligned}
& O T=\frac{a . N .8000}{V-4} \\
& \mathrm{BOD}_{5}=\frac{\left(\mathrm{D}_{0}-\mathrm{D}_{5}\right)-\left(\mathrm{B}_{0}-\mathrm{B}_{5}\right)(1-\mathrm{P})}{\mathrm{P}}
\end{aligned}
$$

Keterangan:

$$
\begin{array}{ll}
\mathrm{BOD}_{5}= & \mathrm{mg} \mathrm{O}_{2} / \text { liter } \\
\mathrm{a} & =\text { Volume titran natrium } \\
& \text { tiosulfat }(\mathrm{ml}) \\
\mathrm{N}= & \text { Nilai ekivalen natrium tiosulfat } \\
\mathrm{V} & \text { Volume botol winkler }(\mathrm{ml}) \\
\mathrm{D}_{0}= & \text { Oksigen terlarut pada blanko } \\
& \text { saat } \mathrm{t}=0\left(\mathrm{mg} \mathrm{O}_{2} / \mathrm{L}\right) \\
\mathrm{D}_{5} \quad= & \text { Oksigen terlarut pada blanko } \\
& \text { saat } \mathrm{t}=5\left(\mathrm{mg} \mathrm{O}_{2} / \mathrm{L}\right) \\
\mathrm{B}_{0}= & \text { Oksigen terlarut pada sampel } \\
& \text { saat } \mathrm{t}=0\left(\text { mg } \mathrm{O}_{2} / \mathrm{L}\right) \\
\mathrm{B}_{5}= & \text { Oksigen terlarut pada sampel } \\
& \text { saat } \mathrm{t}=5\left(\text { mg } \mathrm{O}_{2} / \mathrm{L}\right) \\
\mathrm{P}= & \text { Derajat pengenceran } \\
\mathrm{OT}= & \text { Oksigen terlarut }\left(\mathrm{mg} \mathrm{O}_{2} / \mathrm{L}\right)
\end{array}
$$

e) Parameter total $\mathrm{N}$ diukur awal-akhir di setiap batch feeding menggunakan metode spektrofotometri. Berikut ini langkah - langkah pengukuran total $\mathrm{N}$ :

1) Membuat blanko dengan menambahkan aquades sebanyak 1 $\mathrm{mL}$ ke dalam tabung yang berisi reagent total $\mathrm{N}$;

2) selanjutnya untuk pembuatan sampel, menambah limbah cair pengolahan kopisebanyak $1 \mathrm{~mL}$ ke dalam tabung yang berisi reagen;

3) kemudian kedua tabung ditutup rapat dan dikocok dan didinginkan pada suhu ruangan;

4) menuangkan sampel yang sudah dinetralkan $\mathrm{pH}$ nya dan dimasukkan ke dalam reagen serta 
dilakukan pengocokan;

5) memanaskan sample di dalam reaktor pada suhu $150^{\circ} \mathrm{C}$ selama 2 jam;

6) melakukan pembacaan blanko dan sampel melalui spektrofotometer

f) Parameter C-Organik diukur awalakhir di setiap batch feeding menggunakan metode Walkey dab Black. Berikut ini langkah-langkah pengukuran C-Organik:

1) Menyiapkan larutan pereaksi $\mathrm{K}_{2} \mathrm{Cr}_{2} \mathrm{O}_{7} 2 \quad \mathrm{~N}$ yaitu $19,62 \quad \mathrm{~g}$ ditambah $20 \mathrm{~mL} \mathrm{H}_{2} \mathrm{SO}_{4}$ dilarutkan dalam $200 \mathrm{~mL}$ air bebas ion, larutan standar $5000 \mathrm{ppm} \mathrm{C}$ yaitu 1,25 g glukosa dilarutkan ke dalam $100 \mathrm{~mL}$ air bebas ion;

2) Menyiapkan sampel sebanyak $5 \mathrm{~g}$ yang dimasukkan ke dalam labu takar $100 \mathrm{ml}$;

3) Melakukan penambahan berturutturut $5 \mathrm{ml}$ larutan $\mathrm{K}_{2} \mathrm{Cr}_{2} \mathrm{O}_{7} 2 \mathrm{~N}, 7$ $\mathrm{ml} \mathrm{H}_{2} \mathrm{SO}_{4}$ lalu dikocok dan dibiarkan 30 menit;

4) Menyiapkan larutan standar sebanyak $2 \mathrm{~mL}, 4 \mathrm{ml}, 6 \mathrm{~mL}, 8 \mathrm{~mL}$, $10 \mathrm{~mL}$, dan $12 \mathrm{~mL}$ larutan standar 250 ppm C yang dimasukkan ke dalam labu takar $100 \mathrm{ml}$ lalu ditambahkan $5 \mathrm{ml} \mathrm{H}_{2} \mathrm{SO}_{4}$ dan $7 \mathrm{ml}$ larutan $\mathrm{K}_{2} \mathrm{Cr}_{2} \mathrm{O}_{7} 2 \mathrm{~N}$;

5) Menyiapkan blanko sebagai standar 0 ppm C;

6) Melakukan pengenceran pada masing-masing larutan standar dan blanko dengan air bebas ion dan setelah dingin volume ditepatkan hingga $100 \mathrm{~mL}$, lalu dikocok dan dibiarkan semalam;

7) Melakukan pengukuran keesokan harinya dengan spektrofotometer pada panjang gelombang $580,5 \mathrm{~nm}$.

Perhitungan:

Kadar $\mathrm{C}=$ ppm kurva $\times \mathrm{s} \times \mathrm{fk}$

Keterangan :

Ppm kurva $=$ kadar contoh yang didapat dari kurva regresi hubungan antara kadar deret standar dengan pembacaannya setelah dikurangi blanko

$\mathrm{S} \quad=100 / \mathrm{mg}$ sampel

$\mathrm{Fk} \quad=$ faktor koreksi kadar air $=$ 100/(100 - \% kadar air).

\section{Pengukuran parameter biogas}

Terdapat tiga parameter pengukuran biogas yaitu volume dan komposisi biogas serta perhitungan nilai $\mathrm{C} / \mathrm{N}$. Berikut ini prosedur pengukurannya.

a) Pengukuran volume gas dilakukan dengan mengukur volume biogas yang ditampung pada plastik penampung. Pengukuran ini dilakukan selama 35 hari. Berikut ini merupakan teknik pengukuran volume biogas yang dilakukan saat penelitian;

1) menyiapkan beaker glass $500 \mathrm{~mL}$ dan melakukan pengisian air jernih hingga volume air dalam beaker glass mencapai $250 \mathrm{ml}$;

2) melepaskan tali yang mengikat penampung gas dengan saluran gas secara perlahan;

3) menarik penampung gas dari saluran gas dilakukan secara pelahan kemudian ikat ujung penampung gas secara kuat hingga plastik penampung gas menggembung;

4) menutup saluran gas menggunakan penyumbat plastik dengan segera setelah penampung gas dilepaskan;

5) memasukkan plastik penampung gas ke beaker glass yang sudah diisi air dengan cara menekan secara pelahan menggunakan jari hingga semua permukaan kantong plastik tenggelam;

6) melakukan pengukuran volume biogas dilakukan dengan mengamati kenaikan muka air pada beaker glass.

b) Pengukuran komposisi biogas dilakukan dengan $\mathrm{CO}_{2}$ meter pada biogas yang dihasilkan selama 35 hari. 
Hasil pengukuran ini menjadi dasar penentuan kandungan gas lainnya pada biogas.

c) Pengukuran $\mathrm{C} / \mathrm{N}$ dilakukan setelah nilai karbon dan nitrogen diketahui. Pengukuran tersebut dilakukan setiap awal penambahan feeding dan akhir inkubasi setiap batch feeding. Berikut ini merupakan persamaan yang digunakan dalam menentukan nilai rasio $\mathrm{C} / \mathrm{N}$ (Budiyono et al., 2013).

$\frac{C}{N}$ Ratio $=\frac{\% \text { C Limbah cair kopi } \times \text { bobot }+\% \text { C Kotoran sapi } \times \text { bobot }}{\% \text { Limbah cair kopi } \times \text { bobot }+\% \text { Kotoran sapi } \times \text { bobot }}$

Keterangan : bobot diperoleh dari volume total formulasi limbah cair pengolahan kopi dan volume kotoran sapi

Tahapan proses anaerobik limbah cair pengolahan kopi

Tahapan proses anerobik limbah cair pengolahan kopi dengan metode batch menggunakan 4 tahap batch feeding.

a) Persiapan limbah cair pengolahan kopi yang sudah dinetralkan hingga mencapai $\mathrm{pH}$ 7,1. Starter disisakan sejumlah 2 liter pada digester 2 .

b) Batch pertama memiliki perbandingan starter dan biomassa sebesar 1:1. Batch pertama dilakukan penambahan 2 liter limbah cair pengolahan kopi pada hari ke 0 . Inkubasi dilakukan dari hari ke 0 hingga hari ke 14 .

c) Batch kedua memiliki perbandingan starter dan biomassa sebesar 3:1. Batch kedua dilakukan pengeluaran slurry sejumlah 1 liter dan dilakukan penambahan 1 liter limbah cair pengolahan kopi pada hari ke 14 . Inkubasi dilakukan pada hari ke 14 hingga hari ke 21.

d) Batch ketiga memiliki perbandingan starter dan biomassa sebesar 3,7:0,3. Batch ketiga dilakukan pengeluaran slurry sejumlah 0,6 liter dan dilakukan penambahan 0,3 liter kotoran sapi serta
0,3 liter limbah cair pengolahan kopi pada hari ke 21. Inkubasi dilakukan dari hari ke 21 hingga ke 28.

e) Batch keempat memiliki perbandingan starter dan biomassa sebesar 3,6:0,4. Batch keempat dilakukan pengeluaran slurry sejumlah 0,6 liter dan dilakukan penambahan limbah cair pengolahan kopi sejumlah 0,6 liter pada hari ke 28 . Inkubasi dilakukan pada hari ke 28 hingga hari ke 35.

\section{Analisis Data}

Analisis data dilakukan pada hasil pengamatan data harian, awal dan akhir.Data harian yang diamati meliputi volume dan komposis biogas yang terbentuk, $\mathrm{pH}$ serta suhu kemudian disajikan dalam bentuk grafik dengan sumbu x sebagai lamanya inkubasi (hari) dan sumbu $y$ sebagai parameter pengamatan harian. Pengolahan data hasil penelitian dilakukan pada parameter awal dan akhir limbah cair pengolahan kopi pada setiap batch feeding yang meliputi $\mathrm{COD}, \mathrm{BOD}, \mathrm{C} / \mathrm{N}$. Metode pengolahan data dilakukan dengan menentukan persentase penurunan tingkat parameter pencemaran tersebut. Berikut ini merupakan persamaan persentase penurunan parameter pencemaran limbah cair pengolahan kopi setelah dilakukan penanganan proses anaerobik dengan metode batch feeding. Berikut ini merupakan persamaan persentase penurunan tingkat pencemaran.

$$
\mathrm{Eff}=\frac{\mathrm{AC}-\mathrm{AB}}{\mathrm{AC}} \times 100 \%
$$

Keterangan:

$\begin{aligned} \text { Eff }= & \text { Persentase penurunan tingkat } \\ & \text { pencemaran limbah }(\%) \\ \mathrm{AC}= & \text { Nilai parameter awal pada } \\ & \text { limbah } \\ \mathrm{AB}= & \text { Nilai parameter akhir pada } \\ & \text { limbah }\end{aligned}$




\section{HASIL DAN PEMBAHASAN}

\section{Pembuatan Starter di Digester 1}

Bakteri metanogen merupakan mikroorganisme yang berperan dalam pembentukan biogas. Bakteri tersebut dapat diperoleh dengan mudah dari fermentasi kotoran sapi. Komponen bakteri metanogen yang berasal dari kotoran sapi secara umum adalah Methanosarcina dan Metahanosaeta dengan waktu kinerja yang optimum selama 1-12 hari (Schnurer dan Jarvis, 2010). Starter berasal dari perbandingan kotoran sapi dan air sebesar 1:1 dan diinkubasi selama 30 hari. Hasil penelitian menunjukkan bahwa pada hari ke-12, starter siap digunakan berdasarkan indikator estimasi produksi gas yang dihasilkan.

\section{Inkubasi Adaptasi di Digester 2}

Starter atau efluen yang diperoleh dari kotoran sapi dipindahkan ke digester 2. Inkubasi tahap ini merupakan fermentasi adaptasi starter dari kotoran sapi dengan limbah cair pengolahan kopi (Budihardjo, 2009). Tujuan tahap ini adalah penyesuaian starter dengan limbah cair pengolahan kopi.

Secara umum, fluktuasi nilai $\mathrm{pH}$ pada Gambar 2 dipengaruhi oleh asidifikasi dalam proses anaerobik yang akan menghasilkan asam-asam volatile. Selain itu, fluktuasi $\mathrm{pH}$ pada inkubasi adaptasi dipengaruhi juga oleh pembentukan buffer atau penyangga secara alami pada proses asidifikasi. Menurut Heegde (2010) proses tersebut optimal pada $\mathrm{pH}$ sebesar 5 sampai 6 .

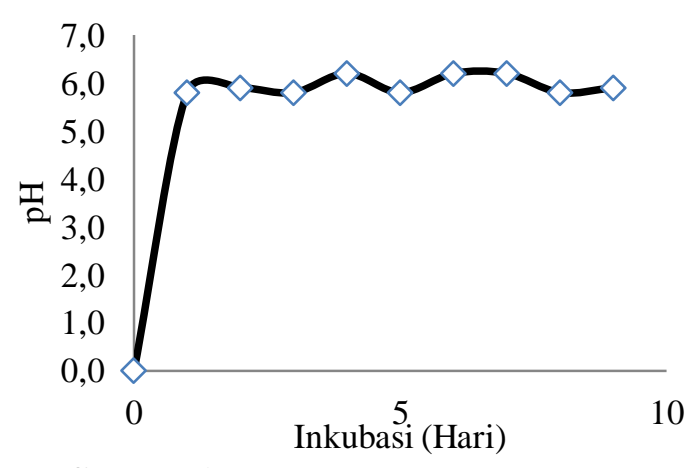

Gambar 2. Fluktuasi pH inkubasi adaptasi

Resistensi starter terhadap pemberian limbah cair pengolahan kopi dapat mempercepat proses degradasi bahan organik karena pertumbuhan bakteri metanogen mulai optimum (Sunarto et al., 2013). Slurry hasil inkubasi adaptasi sudah siap diaplikasikan untuk penanganan limbah cair pengolahan kopi dengan metode batch feeding.

\section{Karakteristik Awal Limbah Cair Pengolahan Kopi}

Berdasarkan Tabel 2 kandungan bahan organik pada limbah cair pengolahan kopi cukup tinggi yang diindikasikan oleh nilai COD, BOD, C dan $\mathrm{N}$. Oleh sebab itu, proses anaerobik digunakan sebagai salah satu alternatif untuk penanganan limbah cair pengolahan kopi.

Tabel 2. Karakteristik awal limbah cair pengolahan kopi di setiap batch feeding

\begin{tabular}{lccccl}
\hline $\begin{array}{l}\text { Para- } \\
\text { meter }\end{array}$ & BF1 & BF2 & BF3 & BF4 & Satuan \\
\hline $\mathrm{pH}$ & 5,2 & 4,7 & 4,7 & 4,7 & - \\
$\mathrm{Suhu}$ & 25,3 & 25,4 & 30,3 & 23 & ${ }^{\circ} \mathrm{C}$ \\
$\mathrm{COD}$ & 3416,7 & 3972,7 & 3242,3 & 2346 & $\mathrm{mg} / \mathrm{L}$ \\
$\mathrm{BOD}$ & 2016 & 2506 & 786 & 1720 & $\mathrm{mg} / \mathrm{L}$ \\
$\mathrm{N}$ & 201,1 & 205 & 129,4 & 15,6 & $\mathrm{mg} / \mathrm{L}$ \\
$\mathrm{C}$ & 906 & 2310 & 726 & 1584 & $\mathrm{mg} / \mathrm{L}$ \\
$\mathrm{C} / \mathrm{N}$ & 7,5 & 7,8 & 12,9 & 46,6 & - \\
\hline Keterangan: & & & & \\
$\mathrm{BF} 1$ & $=$ & Batch Feeding 1 & $\mathrm{BF} 3=$ Batch Feeding 3 \\
$\mathrm{BF} 2$ & $=$ & Batch Feeding 2 & $\mathrm{BF} 3=$ Batch Feeding 4
\end{tabular}




\section{Analisis Pembentukan Biogas}

Proses anaerobik memiliki dua keuntungan. Keuntungan tersebut yaitu menghasilkan biogas yang dapat digunakan sebagai sumber energi dan penurunan daya cemar limbah. Hasil proses anaerobik adalah gas metan, gas karbondioksida, hidrogen dan hidrogen sulfida. Secara umum menurut Gerlach et al. (2013), komposisi biogas terdiri atas $50-70 \%$ gas metan, $24-45 \%$ gas karbondioksida serta $10 \%$ gas-gas lain (sulfur, nitrogen, hidrogen, uap air dan amoniak). Terdapat beberapa parameter yang diamati dalam menganalisis pembentukan biogas pada penelitian yang dilakukan yaitu volume biogas serta prediksi kandungan atau komposisi biogas.

\section{Identifikasi volume biogas}

Biogas merupakan fluida yang berasal dari aktivitas mikroorgansisme dalam merombak atau mendegradasi bahan-bahan organik. Beberapa bakteri yang berperan dalam siklus pembentukan biogas adalah bakterik hidrolitik (hidrolisis), acidlfarming bacteria dan acetogenic bacteria (asidifikasi) serta Methanobacterium, Methanosarcina dan Metanococcus (Nabarlatz et al., 2013). Karakteristik pembentukan biogas akan dipengaruhi oleh aktivitas mikroorganisme dan faktor lingkungan. Kondisi tersebut dapat dilihat dalam Gambar 3 yang menunjukkan fluktuasi nilai volume gas yang terbentuk.

Volume biogas yang terbentuk mengalami peningkatan mulai hari ke 2 hingga hari ke 6 pada setiap batch feeding. Berdasarkan kondisi tersebut dapat disimpulkan bahwa kemungkinan pada tahapan tersebut sedang terjadi waktu generasi dan dilanjutkan dengan kondisi exponential (Pelczar dan Chan, 2008). Titik tertinggi volume biogas terjadi pada hari ke 6 dengan volume biogas sebesar $250 \mathrm{~mL}$.Kondisi (b-d) volume biogas yang terbentuk tidak lebih banyak dibandingkan pada kondisi (a-b).Selain itu kondisi (a-b) memiliki laju pembentukan biogas yang lebih cepat dibandingkan dengan kondisi (b-d).

Terdapat beberapa faktor yang mempengaruhi perbedaan pembentukan volume yang terbentuk yaitu kinerja dan jumlah mikroorganisme berkurang, ketersediaan biomassa yang semakin sedikit dan karakteristik limbah cair pengolahan kopi (Selvamurugan et al., 2010). Pada kondisi (a) setelah hari ke 6 mengalami penurunan volume biogas yang hingga hari ke-14. Kemudian pada kondisi (c) dilakukan penambahan limbah cair pengolahan kopi (untuk menambahkan karbohidrat, protein dan lemak) dan kotoran sapi (untuk menambah bakteri decomposer). Upaya ini dilakukan untuk memperbaharui meningkatan kinerja starter (menambah bakteri metanogen) dan penambahan limbah cair pengolahan kopi (nutrisi) agar volume biogas yang dihasilkan relatif konstan dan tinggi (Budiyono et al., 2013).

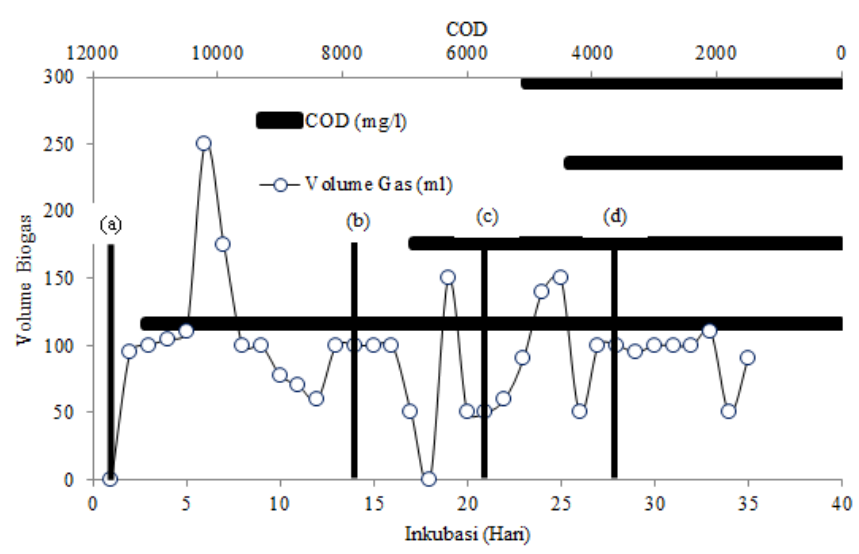

Gambar 3. Fluktuasi volume biogas; (a) Batch feeding pertama: penambahan limbah cair pengolahan kopi kedua (b) batch feeding kedua: Penambahan limbah cair pengolahan kopi kedua; (c) batch feeding ketiga: penambahan limbah cair pengolahan kopi kedua dengan penambahan kotoran sapi; (d) batch fedding keempat: penambahan limbah cair pengolahan kopi keempat 
Kondisi beban pencemaran pada batch feeding 1 yang diindikasikan oleh COD dan BOD campuran (limbah cair kopi dan starter) dengan nilai sebesar $11.160 \mathrm{mg} / \mathrm{L}$ dan $7.720 \mathrm{mg} / \mathrm{L}$ dengan nilai $\mathrm{C} / \mathrm{N}$ sebesar 7,5 memungkinkan siklus pertumbuhan bakteri mengalami tahapan lag, exponential, stasionary dan death. Selain itu batch feeding 1 sebelumnya sudah terdapat starter yang sudah mengalami fase adaptasi sehingga dapat mempercepat siklus hidup mikroorganisme pada fase ini.

Tabel 3 menunjukkan batch feeding 2 dengan perbandingan starter dan biomassa sebesar 3:1, menghasilkan volume biogas tertinggi sebesar $100 \mathrm{ml}$ pada hari ke 16. Penurunan volume biogas pada batch feeding 2 diperkirakan karena pertumbuhan bakteri metanogen mengalami penurunan dan jumlah biomassa semakin berkurang. Kondisi tersebut mengakibatkan reduksi nilai $\mathrm{C} / \mathrm{N}$ relatif rendah yaitu sebesar $20,72 \%$. Batch feeding 3 dengan perbandingan starter dan biomassa sebesar 3,7:0,3 diperkirakan mengalami tahapan exponential atau waktu generasi yang cepat dengan indikasi jumlah biogas yang dihasilkan meningkat sebesar $150 \mathrm{~mL}$ dan diprediksikan tanpa disertai tahapan stationary. Ketersediaan subtrat yang lebih sedikit dibandingkan jumlah bakteri metanogen mempengaruhi produksi biogas (Saputra et al., 2010).

Batch feeding 3 memiliki tingkat degradasi $\mathrm{C} / \mathrm{N}$ tinggi sebesar $77,00 \%$. Batch feeding 4 dengan perbandingan starter dan biomassa sebesar 3,4:0,6 produksi biogas meningkat. Kemungkinan pada batch feeding 4 mengalami tahapan exponential dan stationary. Produksi biogas yang dihasilkan sebesar 100-110 ml dengan tingkat degradasi rasio $\mathrm{C} / \mathrm{N}$ sebesar 70,72\%. Kondisi ini terjadi karena konsentrasi dan kinerja bakteri metanogen menurun. Methanosarcina dan Metahanosaeta dengan waktu kinerja yang optimum selama 1-12 hari (Schnurer dan Jarvis, 2010).
Tabel 3. Produksi biogas tertinggi pada setiap batch

\begin{tabular}{lcccc}
\hline Parameter & BF1 & BF2 & BF3 & BF4 \\
\hline $\begin{array}{l}\text { Perbandingan } \\
\text { starter dan } \\
\text { biomassa } \\
\text { Waktu inkubasi }\end{array}$ & $1: 1$ & $3: 1$ & $3,7: 0,3$ & $3,4: 0,6$ \\
(hari) & & & & \\
$\begin{array}{l}\text { COD campuran } \\
\text { (mg/L) }\end{array}$ & 11.160 & 6.867 & 4.372 & 5.074 \\
$\begin{array}{l}\text { BOD campuran } \\
\text { (mg/L) }\end{array}$ & 4.760 & 4.450 & 3.122 & 2.342 \\
$\begin{array}{l}\text { Titik tertinggi } \\
\text { (Hari ke) }\end{array}$ & 6 & 19 & 25 & 33 \\
$\begin{array}{l}\text { Volume biogas } \\
\text { titik tertinggi } \\
\text { (mL) }\end{array}$ & 250 & 150 & 150 & 110 \\
\hline
\end{tabular}

Keterangan: COD dan BOD campuran = Nilai
COD dan BOD dari limbah cair kopi
dan starter

Proses anaerobik pada digester 2 menghasilkan pola pembentukan biogas tertinggi pada setiap batch feeding terjadi antara hari ke 5-6, dengan estimasi pada titik tersebut aktivitas bakteri mengalami fase stationary dan dilanjutkan fase death dengan indikasi penurunan produksi biogas yang cenderung curam. Pada hari 1-3 secara berurutan diestimasikan aktivitas bakteri mengalami fase leght dan eksponential berdasarkan pola pembentukan biogas pada Gambar 2.

\section{Identifikasi komposisi biogas}

Berdasarkan penelitian terdapat komposisi biogas pada semua batch feeding dari digester. Komposisi biogas disajikan pada Tabel 4.

Rata-rata dalam 4 liter starter dan limbah cair kopi dalam waktu 35 hari menghasilkan komposisi biogas yang sama pada setiap batch yang terdiri atas $56,3 \%$ gas metan; 34,33 \% gas karbondioksida serta $9,36 \%$ gas-gas dengan volume kecil. Salah satu hal yang mempengaruhi pembentukan biogas adalah rasio $\mathrm{C} / \mathrm{N}$ (Windyasmara, 2012). Nilai rasio $\mathrm{C} / \mathrm{N}$ pada kultur limbah cair pengolahan kopi 
sebesar 7,5-46,1 \%. Nilai N (total N) lebih kecil dibandingkan dengan nilai $\mathrm{C}$ organiknya sehingga pembentukan gas metan kurang optimal. Selain itu, kondisi meshopilic pada proses pembentukan biogas mempengaruhi proses anaerobik yang bekerja secara pararel yang meliputi hidrolisis, asidifikasi dan metanonegenis.

Tabel 4. Estimasi hasil perhitungan komposisi biogas pada proses anaerobic limbah cair pengolahan kopi di kondisi semua batch feeding

\begin{tabular}{lcccc}
\hline & \multicolumn{3}{c}{ Jenis dan Komposisi Biogas } \\
\cline { 2 - 4 } Proses & $\begin{array}{c}\text { Gas } \\
\text { metan } \\
\end{array}$ & $\begin{array}{c}\text { Gas } \\
\text { karbon } \\
\text { dioksida } \\
\left(\mathrm{CH}_{4}\right)\end{array}$ & $\begin{array}{c}\text { Gas } \\
\text { dengan } \\
\text { volume } \\
\text { kecil }\end{array}$ & $\begin{array}{c}\text { Jumlah } \\
(\%)\end{array}$ \\
\hline BF1 & 56,33 & 34,32 & 9,35 & 100,00 \\
BF2 & 56,31 & 34,34 & 9,35 & 100,00 \\
BF3 & 56,27 & 34,35 & 9,38 & 100,00 \\
BF4 & 56,29 & 34,31 & 9,40 & 100,00 \\
Rata - & 56,30 & 34,33 & 9,36 & 100,00 \\
rata & & & & \\
\hline
\end{tabular}

Pada kondisi mesophilic proses hidrolisis akan menghasilkan senyawa $\mathrm{CO}_{2}$ dan $\mathrm{H}_{2}$ yang tidak terlalu banyak (Darmanto et al., 2012) sehingga pembentukan gas metan dan gas karbondioksida kurang optimal. Proses anaerobik akan menghasilkan enzim yang optimum bekerja pada kondisi thermophilic (Selvamurugan et al., 2010). Kondisi thermophilic gesekan antar partikel terjadi dengan cepat sehingga mempengaruhi perombakan bahan organik menjadi gas metan. Pembentukan gas metan juga dipengaruhi oleh kandungan bahan organik yang diindikasikan oleh nilai penurunan dan waktu fermentasi pada COD dan BOD. Tingginya beban pencemaran yang diidikasikan oleh COD dan BOD dapat meningkatkan pembentukan volume biogas. Digester 2 tidak menggunakan pengaduk, pengadukan hanya dilakukan dengan cara menggoyang-goyang digester. Hal ini mengakibatkan biogas yang dihasilkan dari reaksi kimia masih terperangkap bagian tengah slurry limbah cair pengolahan kopi (Darmanto et al., 2012).

\section{Nilai $\mathrm{C} / \mathrm{N}$}

$\mathrm{C} / \mathrm{N}$ merupakan perhitungan yang digunakan untuk mengetahui perbandingan kandungan Karbon atau $\mathrm{C}$ organik serta Nitrogen (total $\mathrm{N}$ ) dalam suatu zat. Proses anerobik sangat membutuhkan unsur $\mathrm{C}$ dan $\mathrm{N}$. Hal ini disebabkan oleh proses anaerobik tidak mengabsorbsi oksigen sehingga unsur $\mathrm{C}$ dan $\mathrm{N}$ digunakan sebagai media pertumbuhan mikroorganisme atau bakteri (Pandey and Soupir, 2011). C organik digunakan untuk membentuk sel karbon, asam volatile, gas metan $\left(\mathrm{CH}_{4}\right)$ dan gas karbondioksida $\left(\mathrm{CO}_{2}\right)$ sedangkan unsur $\mathrm{N}$ digunakan untuk nutrisi atau makanan serta pembelahan sel pada mikroorganisme yang berperan dalam proses anaerobik (Saputra et al., 2010). Pada dasarnya nilai $\mathrm{C}$ dan $\mathrm{N}$ dimanfaatkan sebagai biofermentasi dalam proses anaerobik. Nilai $\mathrm{C} / \mathrm{N}$ relatif tinggi akan meningkatkan pertumbuhan bakteri yang berakibat pada pembentuk gas karbondioksida yang tinggi sedangkan jika nilai rasio $\mathrm{C} / \mathrm{N}$ rendah maka nitrogen akan berakumulasi untuk membentuk gas ammonia (Velmourougane, 2011). COD dan BOD pada limbah cair pengolahan kopi yang mengindikasikan adanya $\mathrm{C}$ dan $\mathrm{N}$ memiliki pengaruh pada jumlah pengubahan bahan organik menjadi gas metan oleh bakteri metanogen.

Persentase penurunan rasio $\mathrm{C} / \mathrm{N}$ pada penanganan limbah cair pengolahan kopi dengan proses anaerobik memiliki nilai 53,35 \% (batch feeding 1); 20,70\% (batch feeding 2); 77,00 \% (batch feeding 3) dan 70,72\% (batchfeeding 4) (Gambar 4). Reduksi terendah terjadi pada pada penambahan limbah cair pengolahan kopi kedua dengan persentase penurunan sebesar 20,70 \% sedangkan nilai persentase penurunan tertinggi terjadi pada penambahan limbah cair pengolahan dan kotoran sapi (penambahan ketiga) dengan 
nilai persentase penurunan sebesar 77,00 $\%$. Hal tersebut terjadi karena pada nilai penurunan rasio $\mathrm{C} / \mathrm{N}$ sebesar $20,70 \%$ diprediksikan terjadi penurunan jumlah bakteri metanogen atau bakteri lainnya yang terlibat pada proses anaerobik. Umur fungsional bakteri metanogen hanya 2-12 hari (Schnurer dan Jarvis, 2010).

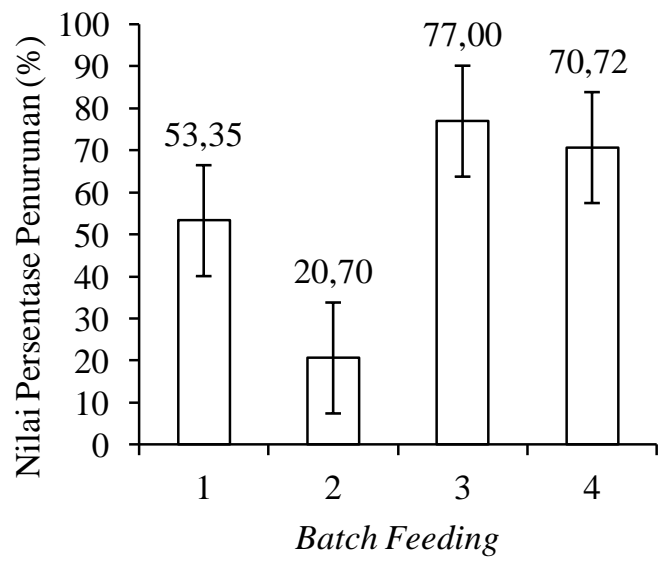

Gambar 4. Nilai persentase penurunan $\mathrm{C} / \mathrm{N}$ (rasio $\mathrm{C} / \mathrm{N}$ )

Aktivitas bakteri diprediksikan menurun sehingga hidrolisis, asidifikasi serta metanogenesis bahan-bahan organik sehingga tingkat penggunaan unsur $C$ dan $\mathrm{N}$ mengalami penurunan dalam proses anaerobik. Kemudian peningkatan nilai penurunan $\mathrm{C} / \mathrm{N}$ yang tinggi dengan nilai $77,00 \%$ yang disebabkan oleh penambahan kotoran sapi yang diencerkan dengan limbah cair pengolahan kopi. Penambahan ini diestimasikan dapat peningkatan jumlah dan aktivitas bakteri metanogen dalam mereduksi $\mathrm{C} / \mathrm{N}$ biomassa.

Batch feeding 1 memiliki persentase penurunan $\mathrm{C} / \mathrm{N}$ sebesar $53,35 \%$ menghasilkan volume biogas yang paling tinggi dengan nilai $250 \mathrm{ml}$. Hal ini terjadi karena ketersediaan bahan organik berupa $\mathrm{C}$ dan $\mathrm{N}$ relatif tinggi yaitu sebesar 906 $\mathrm{mg} / \mathrm{L}$ dan $201 \mathrm{mg} / \mathrm{L}$ (Tabel 2) serta kondisi bakteri metanogen diprediksikan pada fase pertumbunan exponential. Methanosarcina dan Metahanosaeta dengan waktu kinerja yang optimum selama 1 - 12 hari (Schnurer dan Jarvis, 2010).

Pada batch feeding 2 persentase penurunan $\mathrm{C} / \mathrm{N}$ menurun sehingga produksi biogas tidak setinggi pada kondisi batch feeding 1. Fase ini diprediksikan bakteri metanogen memiliki populasi yang berkurang karena mengalami kematian. Pada batch feeding 3 hingga 4 dengan nilai persentase penurunan $\mathrm{C} / \mathrm{N}$ secara berurutan yaitu $77,00 \%$ dan $70,77 \%$ menghasilkan biogas yang cenderung dalam keadaan eksponential dan stationary. Berdasarkan uraian tersebut digester 2 yang digunakan untuk proses anaerobik limbah cair kopi mampu menurunkan $\mathrm{C} / \mathrm{N}$ sebesar $77,00 \%$.

\section{Kualitas Air \\ Suhu}

Suhu merupakan salah satu faktor yang penting dalam proses anaerobik. Peningkatan suhu menunjukkan reaksi mikroorganisme dalam menguraikan limbah cair pengolahan kopi pada proses anaerobik. Reaksi kimia tersebut berupa perombakan bahan-bahan organik menjadi dua komponen fluida yaitu biogas dan slurry dengan disertai pelepasan energi panas (Pandey dan Soupir, 2011). Kondisi ini sesuai pada proses anaerobik limbah cair pengolahan kopi (Gambar 5). Kenaikan suhu yang terjadi batch feeding 1 dengan suhu $24,9-29^{\circ} \mathrm{C}$ disertai kenaikan volume gas sebesar $250 \mathrm{ml}$. Kondisi tersebut terulang batch feeding 2 dan 3 dengan suhu $27{ }^{\circ} \mathrm{C}$ hingga mencapai $28,8^{\circ} \mathrm{C}$ dapat menghasilkan biogas sebesar $150 \mathrm{~mL}$. Tingginya suhu pada batch feeding 1 dibandingkan batch feeding 2 hingga 4 disebabkan oleh kecepatan respirasi dan peningkatan reaksi kimia oleh mikrorganisme (Kristanto, 2004). 
3 (a)

(b)

(c)

(d)

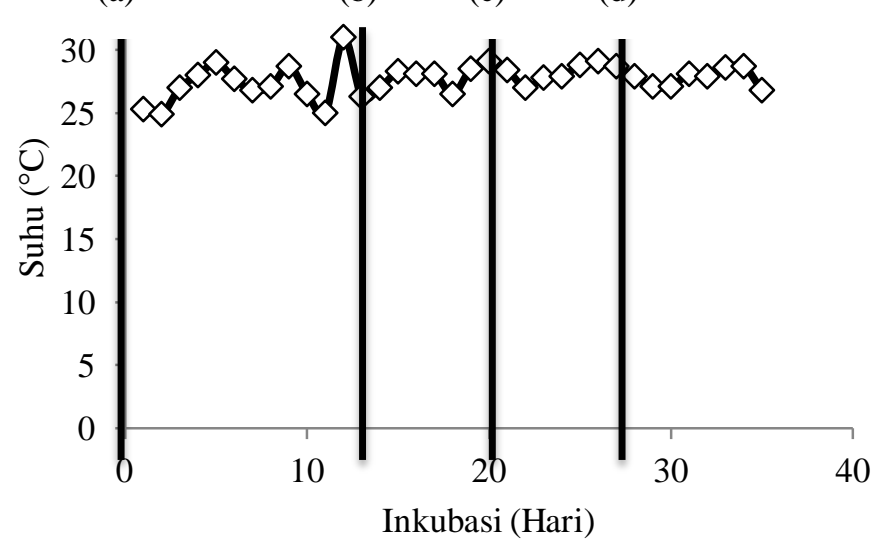

Gambar 5. Fluktuasi suhu: (a) Batch feeding pertama: penambahan limbah cair pengolahan kopi kedua (b) batch feeding kedua: Penambahan limbah cair pengolahan kopi kedua; (c) batch feeding ketiga: penambahan limbah cair pengolahan kopi kedua dengan penambahan kotoran sapi; (d) batch fedding keempat: penambahan limbah cair pengolahan kopi keempat

Gambar 5 menunjukkan bahwa karakteristik peningkatan suhu terjadi setelah hari ke 1 hingga hari ke 3 setelah dilakukan penambahan biomassa. Menurut Schnurer dan Jarvis (2010), proses hidrolisis dan asidifikasi terjadi pada suhu $25^{\circ} \mathrm{C}$, sedangkan peningkatan suhu terjadi pada proses metanogenesis. Aktivitas bakteri metanogen dalam konversi asam asetat menyebabkan pelepasan energi dalam bentuk energi panas sehingga mengakibatkan perubahan kondisi suhu proses mesophilic menjadi termophilic (Ziemiski dan Frac, 2012). Hal tersebut dapat disimpulkan bahwa metanogenesis berlangsung optimal terjadi pada hari 1 hingga hari ke 3 setelah dilakukan penambahan biomassa berdasarkan parameter suhu pada digester 2 .

\section{Derajat keasaman $(\mathrm{pH})$}

Limbah cair pengolahan kopi di Perkebunan Kopi Sidomulyo Kabupaten Jember memiliki pH sebesar 4,7-5,2 sehingga memiliki kondisi yang asam.
Menurut Kementerian Lingkungan Hidup Republik Indonesia (2014), batas aman pH limbah cair industri kopi berkisar antara 69. Fluktuasi $\mathrm{pH}$ pada proses anaerobik dapat dilihat pada pada Gambar 6. Nilai $\mathrm{pH}$ hasil proses anaerobik berkisar antara 5,2-7,1. Nilai batch feeding 1 meningkat dari 5,2 mencapai 6,3 dan untuk nilai $\mathrm{pH}$ selanjutnya cenderung stabil dengan rentang 6,8-7,1 meskipun tetap terjadi penurunan nilai $\mathrm{pH}$ pada setiap batch feeding. Penurunan $\mathrm{pH}$ tersebut terjadi karena perubahan suhu serta interaksi mikroorganisme atau bakteri metanogen oleh oksigen (Budiyono et al., 2013). Selain itu kondisi tersebut juga disebabkan oleh pembentukan larutan buffer serta asidifikasi sedang berlangsung.

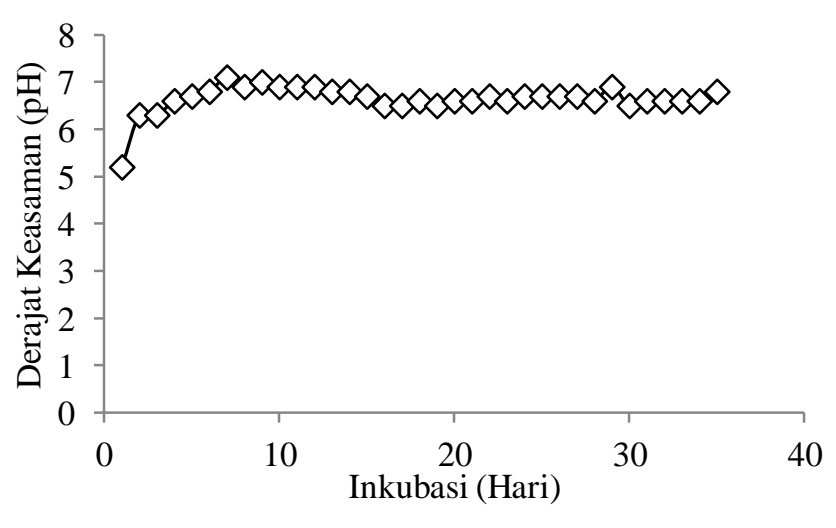

Gambar 6. Fluktuasi nilai pH

Chemical Oxygen Demand (COD) dan Biochemical Oxygen Demand (BOD)

Parameter yang digunakan untuk tingkat pencemaran limbah berdasarkan kandungan oksigen dalam badan air untuk bereaksi secara kimia dan biologi yaitu COD dan BOD yang dinyatakan dalam $\mathrm{mg} / \mathrm{L}$. Mikroorganisme yang terdapat pada limbah cair pengolahan kopi membutuhkan oksigen untuk mengoksidasi bahan organik, sintesa sel dan oksidasi sel. Oleh sebab itu dapat disimpulkan bahwa uji COD dan BOD digunakan untuk mengetahui perbedaan pemanfaatan oksigen untuk mendegradasi 
bahan organik secara kimia dan biologi sebelum penanganan limbah cair. Selain itu kandungan bahan-bahan organik serta logam berat yang diindikasikan oleh COD yang dibutuhkan untuk keberlangsungan proses hidrolosis, asidifikasi hingga metanogenesis dalam pembentukan biogas (Neves et al., 2005). Hasil penanganan proses anaerobik pada limbah cair pengolahan kopi dengan metode batch feeding berdasarkan persentase penurunan disajikan pada Gambar 7.

Nilai persentase penurunan COD lebih tinggi dibandingkan dengan persentase penurunan BOD. BOD merupakan indikator degradasi oksigen secara biologi (aktivitas mikroorganisme). Namun degradasi oleh oksidasi yang dilakukan kalium dikromat relatif lebih kuat, sehingga mengakibatkan nilai COD lebih besar dibandingkan nilai BOD (Kristanto, 2004).

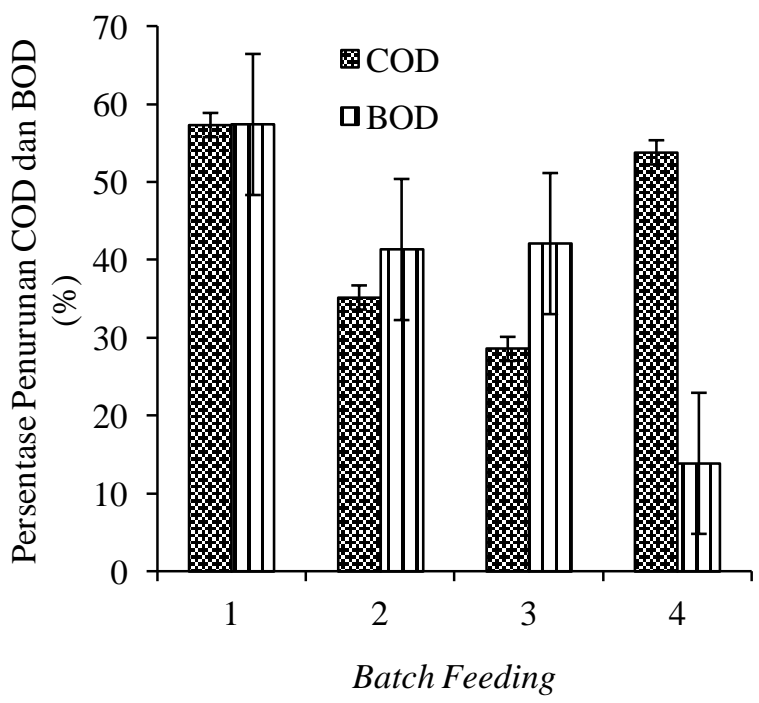

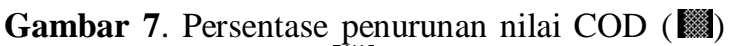
dan BOD (I||l|)

Pada hari ke-21 dilakukan penambahan limbah cair pengolahan kopi dan kotoran sapi sehingga mengakibatkan nilai BOD awal limbah cair pengolahan kopi lebih rendah dibandingkan dengan nilai BOD pada hari ke 14 hingga ke 35.Kinerja bakteri metanogen optimum selama 2-12 hari (Schnurer dan Jarvis,
2010). Digester 2 tidak dilengkapi dengan pengaduk. Kondisi ini mengakibatkan homogenitas atau pencampuran antara starter dan biomassa berjalan lambat (Zaman, 2010). Homogenitas partikel yang lambat berpengaruh pada penurunan nilai COD dan BOD pada limbah cair pengolahan kopi. Persentase penurunan tertinggi pada COD sebesar $57,35 \%$ dan BOD sebesar $57 \%$ dengan tingkat produksi biogas yang tinggi yaitu $250 \mathrm{ml}$.

Degradasi COD dipengaruhi oleh proses hidrolisis pada senyawa polimer. Hal ini sesuai dengan data persentase penurunan COD. Pada pola pertama, proses anaerobik yang terjadi relatif lebih lama atau memiliki waktu degradasi yang lebih panjang yaitu 14 hari. Kondisi tersebut mengakibatkan proses hidrolisis senyawasenyawa polimer yang menghasilkan senyawa monomer yang lebih banyak. Menurut Rambe et al. (2014), semakin lama waktu tinggal bahan pencemar pada kondisi anaerobik maka proses hidrolisisnya semakin optimal.

\section{KESIMPULAN}

Proses anaerobik pada digester 2 menghasilkan pola pembentukan volume biogas tertinggi pada setiap batch feeding pada hari ke 5-6 dan disertai kencerungan penurunan volume biogas setelah hari itu. Peningkatan volume biogas dimulai dari hari ke $2(95 \mathrm{ml})$ hingga hari ke $6(250 \mathrm{ml})$ pada setiap feeding. Pola produksi biogas pada proses anaerobik limbah cair pengolahan kopi ini menggunnakan model digester 2 (batch digester) dapat menjadi alternatif penambahan variasi komposisi input atau feeding, dengan estimasi hari ke 5 atau 6 agar volume biogas yang dihasilkan stabil.

Persentase tertinggi penurunan parameter tingkat pencemaran limbah cair pengolahan kopi terjadi pada setiap feeding berbeda. Penurunan COD dan BOD terjadi pada batch feeding dengan perbandingan starter dan biomassa 1:1 secara berurutan yaitu $57,35 \%$ dan 
$57,42 \%$. Persentase penurunan rasio $\mathrm{C} / \mathrm{N}$ tertinggi sebesar $77,00 \%$ terjadi pada batch feeding dengan perbandingan starter dan biomassa 3,7:0,3. Parameter suhu dan $\mathrm{pH}$ limbah cair pengolahan kopi selama diinkubasi memiliki rentang nilai secara berurutan sebesar $24,9-31^{\circ} \mathrm{C}$; dan 6,5-7,1.

\section{UCAPAN TERIMA KASIH}

Ucapa terima kasih ditujukan kepada Kementerian Riset dan Teknologi Republik Indonesia, segenap civitas Fakultas Teknologi Pertanian Universitas Jember dan Jurusan Teknik Lingkungan Institut Teknologi Sepuluh Nopember yang telah memberikan bantuan fasilitas untuk menyelesaikan penelitian ini.

\section{DAFTAR PUSTAKA}

Bruno, M. dan Oliveira, R. A. D. 2008. Anaerobic treatment of waste from coffe pulping in upflow anaerobic slude blanket (UASB) in two stage. International Proceedings. FCAVUNESP, Brazil.

Budiyono, Pratiwi, E. M., dan Sinar, I. N. Y. 2013. Pengaruh metode fermentasi, komposisi umpan, $\mathrm{pH}$ awal dan variasi pengenceran terhadap produksi biogas dari vinasse. Jurnal Penelitian Kimia, 9 (1): $1-12$.

Darmanto, A., Soeparman, S. dan Widhiyanuariawan. 2012. Pengaruh kondisi temperatur mesophilic $\left(35^{\circ} \mathrm{C}\right)$ dan thermophilic $\left(55^{\circ} \mathrm{C}\right)$ anaerob digester kotoran kuda terhadap produksi biogas. Jurnal Rekayasa Mesin, 3 (2): 317-326.

Dinas Pertanian dan Perkebunan Kabupaten Jember. 2015. Komoditi pertanian. (http://pertanian.jatimprov.go.id/index.p $\mathrm{hp} /$ sentra-hortikultura/14-kab-jember). [Diakses tanggal 28 Februari 2015].

Gerlach, F., Grieb, B. dan Zerger, U. 2013.Sustainable Biogas Production: A Handbook for Organic Farmers. FiBL Projekte GmbH, Jerman.
Heegde, F. T. 2010. Domestic Biogas Plants Sizes and Dimensions. SNV Netherlands Development Organisation, Netherland.

Kementerian Lingkungan Hidup Republik Indonesia. 2014. Peraturan Meteri Negara Ligkungan Hidup Nomor 5 Tahun 2014. Kementerian Lingkungan Hidup Republik Indonesia, Jakarta.

Kementerian Pertanian Republik Indonesia. 2012. Peraturan Meteri Pertanian Nomor 52/Permentan/Ot.140/9/2012 tentang Pedoman Penangnan Pascapanen Kopi. Kementerian Pertanian Republik Indonesia, Jakarta.

Kristanto, P. 2004. Ekologi Industri. Penerbit Andi, Yogyakarta.

Nabarlatz, Beltran, Soraca dan Bonila. 2013. Biogas production by anaerobic digestation of wastewater from palm oil mill industry. Cienca, Tecnology and Future Journal, 5 (2): 73-84.

Neves, Ribeiro, Olivier dan Alves. 2005. Anaerobic Digestion of Coffe Waste. ADSW2005 Conference Proceedings. Centro de Engenharia Biological Universidade do Minho, Portugal.

Novita, E. 2012. Desain Pengolahan pada Agroindustri Kopi Robusta Menggunakan Modifikasi Teknologi Olah Basah Berbasis Produksi Bersih. Program Studi Pengolahan Sumber Daya Alam dan Lingkungan Institut Pertanian Bogor, Bogor.

Pandey, P. K. dan Soupir, M. L. 2011. Escherichia coli inactivation kinetics in anaerobic digestion of dairy manure under moderate, mesophilic and thermophilic temperatures. Springer Open Journal, pp: 1-18.

Pelczar, M. J. dan Chan, E. C. S. 2008.Elements of Microbiology. New York: McGraw-Hill Book Company.

Pramdono, D dan Susanto. J. P. 2007. Biogas sebagai energi alternatif antara mitos dan fakta ilmiah. Jurnal Teknik Lingkungan, 8 (1): 34-42. 
Rambe, S. M., Irianya dan Irvan. 2014. Pengaruh waktu tinggal terhadap reaksi hidrolisis pada pra-pembuatan biogas dari limbah cair pabrik kelapa sawit. Jurnal Dinamika Penelitian Industri, 25 (1): 23-30.

Saputra, T., Triatmojo, S. dan Pertiwiningrum, A. 2010.Produksi biogas dari campuran feses sapi dan ampas tebu (bagasse) dengan rasio $\mathrm{C} / \mathrm{N}$ yang berbeda. Buletin Peternakan, 34 (2): 114-122.

Sariadi. 2012. Pengolahan limbah cair kopi dengan metode elektrokoagulasi. Politeknik Negeri Lhokseumawe, Medan.

Schnurer, A. dan Jarvis, A. 2010.Microbial Handbook for Biogas Plant. Avfall Sverige (Swedish Waste Management) and Swedish Gas Centre (SGC), Swedia.

Selvamurugan, Doraisamy, Maheswari dan Nandakumar. 2010. High rate anaerobic treatment of coffee processing wastewater using upflow anaerobic hybrid reactor. Journal of Environmental, Helath, Science and Engineering, 7 (2): 129-136.

Sunarto, Pangastuti, A. dan Mahajoeno, E. 2013. Karakteristik metanogen selama proses fermentasi anaerob biomassa limbah makanan. Jurnal Eksains, 5 (1): 44-57.

Utomo, D. T., Hadiwidodo, M. dan Sudarno. 2014. Pengaruh pengadukan dan variasi feeding terhadap pembentukan biogas dari sampah dapur rumah makan pada reaktor batchdengan aktivator feses sapi (Bos taurus). Jurnal Teknik Lingkungan, 3 (2): 1-8.

Velmourougane, K. R. K. 2011. Chemical and microbiological change during vermicomposting of coffee pulp using exotic (Eudrilus Eugenia) and native earthworm (Peronyx ceylanesis) species. Biodegradation, 22: 497-507.

Wahyuni, S. 2013. Biogas: Energi Alternatif Pengganti BBM, Gas dan Listrik. Cetakan I. PT Agromedia Pustaka, Jakarta.
Windyasmara, L., Pertiwiningrum, A. dan Yusiati, L., M. 2012. Pengaruh jenis kotoran ternak sebagai substrat dengan penambahan seresah daun jati (Tectona grandis) terhadap karakteristik biogas pada proses fermentasi. Buletin Peternakan, 36 (1): 40-47.

Zaman, N. Q. 2010. The applicability of batch test to assss biomethanation potential of organic waste and asses scale up to continous reactoc system. Environmental Engineering University of Canterbury, New Zealand.

Ziemiski, K. dan Frac, M. 2012. Methane fermentation process as anaerobic digestion of biomass: Transformations, stage and microorganisms. African Journal of Biotechnology, 11 (8): 41274139. 